\title{
MODERATING STRUCTURAL EQUATION MODELING DENGAN PARTIAL LEAST SQUARE PADA PEMODELAN PENERIMAAN DAN PENGGUNAAN DOMPET DIGITAL DI KOTA SEMARANG
}

\author{
Muk rimatun Nisa ${ }^{1}$, Sudarno $^{2}$, Sugito $^{3}$ \\ 1,2,3 Departemen Statistika, Fakultas Sains dan Matematika, Univarsitas Diponegoro \\ email: mukrimatunniisa@gmail.com
}

\begin{abstract}
Digital wallets (e-wallets) are a technology that provides a new perspective for the public on non-cash payments that are far more practical and secure in trans actions. The purpose of this study is to determine the factors that influence the success or failure of implementing digital wallets (e-wallets) using the variant-based StructuralEquation Modeling method (Partial Least Square). In this decade, an approach has been developed that allows the relationship between an independent variable to the dependent variable which is influenced by other latent variables called Moderating Structural Equation Modeling (MSEM), so this study uses MSEM by measuring it using the ping method. The results of the analysis show that the factors that influence acceptance defined as interest in using the technology are social influences, faciliating conditions and consumerhabits. Meanwhile, the factors that influence the use of digital wallets which are defined as usage behavior are interest in use and conditions that facilitate. The use of digital wallets (e-wallets) is also indirectly influenced by social influences, conditions that facilitate and consumer habits. the factor of supporting facilities fromthe is suer of digital wallets (e-wallets) is a factor that affects directly and indirectly the use of digital wallets (e-wallets). Analysis of Moderating Structural Equation Modeling (MSEM) using the ping method results that experience does not affect the acceptance and use of digital wallets (e-wallets) as moderation
\end{abstract}

Keywords: Acceptance and Use Model, Digital Wallet (E-wallet), Partial Least Square, Moderating Structural Equation Modeling.

\section{PENDAhUluan}

Pada era sekarang ini industri fintech berkembang sangat pesat. Teknologi ini menawarkan berbagai keunggulan diantaranya mengedepankan kecepatan, kemudahan dan efisinsi. Selain itu dompet digital ( $e$-wallet) merupakan teknologi yang memberikan pandangan baru bagi masyarakat tentang pembayaran non-tunai yang jauh lebih praktis dan aman dalam bertransaksi, oleh karena itu dirasa perlu adanya penelitian tentang penerimaan dan penggunaan teknologi dompet digital ( $e$-wallet) bagi pengguna. Penerimaan disini didefinisikan sebagai minat pengguna untuk menggunakan suatu teknologi (behavioral intentions). Adanya minat penggunaan konsumen akan menimbulkan perilaku kebiasaan menggunakan suatu teknologi (use behavior). Variabel yang ada pada penelitian ini merupakan variabel tidak terukur, sehingga digunakan Structural Equaition Modeling (SEM). SEM adalah teknik analisis untuk menguji secara simultan sebuah hubungan yang dibentuk dari salah satu atau lebih variabel bebas atau variabel tidak bebas yang tidak terukur. Penggunaan SEM yang berbasis covariance (CBSEM) dengan asumsi parametrik yaitu harus memenuhi asumsi normal multivariate dan sampel yang digunakan besar. Pada penelitian ini tidak memenuhi asumsi normalitas dan data yang digunakan sedikit sehingga digunakan SEM yang berbasis variance yaitu Partial Least Square (PLS). PLS dapat digunakan untuk model sangat kompleks, selain itu juga dapat menganalisis model dengan efek moderasi (MSEM). Penelitian ini bertujuan untuk mengetahui faktor-faktor yang mempengaruhi sukses atau tidaknya penerapan teknologi dompet digital (e-wallet) dan melakukan ideptifikasi pengaruh pengalaman apakah memperkuat atau memperlemah faktor-faktor tersebut dalam mempengaruhi sukses atau tidaknya penerapan dompet digital (e-wallet) menggunakan Moderating Structural Equation Modeling (MSEM) dengan Metode Ping. 


\section{TINJAUAN PUSTAKA}

\subsection{Penerimaan dan Penggunaan Teknologi}

Semakin besar penerimaan teknologi yang baru maka semakin besar kemauan pemakai untuk merubah kegiatan yang sudah ada dalam penggunaan serta usaha untuk memulai secara nyata pada teknologi yang baru. Tetapi jika tidak mau menerima teknologi yang baru, maka perubahan teknologi tersebut tidak memberikan keuntungan yang banyak bagi organisasi atau perusahaan (Pikkarainen et al. , 2004). Dasar penerimaan suatu teknologi adalah nilai manfaat dan kemudahan dalam penggunaan teknologi besar maka penerimaan pengguna teknologi tersebut menjadi meningkat. Vankatesh et al. (2012) mendefinisikan penerimaan sebagai behavioral intentions yaitu minat konsumen untuk menggunakan suatu teknologi, sedangkan penggunaan didefinisikan sebagai use behavior yaitu perilaku kebiasaan konsumen dalam menggunakan suatu teknologi.

Berdasarkan penelitian yang telah dilakukan vankatesh et al. (2012) faktor-faktor yang mempengaruhi penerimaan dan penggunaan suatu teknologi antara lain social influence, hedonic motivation, price value, faciliating conditions dan habit. Semakin besar pengaruh yang diberikan lingkungan sekitar terhadap seseorang untuk menggunakan suatu teknologi yang baru maka semakin besar minat yang timbul dari seseorang tersebut untuk menggunakannya (Vankatesh et al. , 2012). Pendapat lain yang mendukung hedonic motivation yaitu Van der Heijden (2004) menyatakan bahwa hedonic motivation mempengaruhi penerimaan dan penggunaan teknologi secara langsung. Dalam konteks konsumen, hedonic motivation juga telah ditemukan sebagai penentu penting penerimaan dan penggunaan teknologi (Brown dan Vankatesh, 2005). Menurut penelitian yang dilakukan oleh Harsono dan Suryana (2014) faciliating conditions memiliki pengaruh terhadap behavioral intentions serta memiliki pengaruh langsung terhadap use behavior. Selanjutnya faktor struktur biaya dan harga menurut penelitian yang dilakukan oleh vankatesh at al. (2012) berpengaruh signifikan terhadap penggunaan teknologi konsumen. Selain itu juga menyatakan ada pengaruh yang signifikan dari kebiasaan konsumen pada penggunaan teknologi pribadi ketika mereka menghadapi lingkungan yang beragam dan selalu berubah dan dalam penelitian tersebut menyatakan bahwa studi dalam pisikologi telah menemukan bahwa pengalaman dapat memoderasi pengaruh dari minat penggunaan dan perilaku penggunaan suatu teknologi.

\subsection{Dompet Digital (E-Wallet)}

Berdasarkan peraturan Bank Indonesia dompet digital (e-wallet) merupakan layanan elektronik untuk menyimpan data instrumen pembayaran antara lain alat pembayaran, yang dapat menampung dana dan untuk melakukan pembayaran. Fungsi yang paling penting dari dompet digital (e-wallet) yaitu otentikasi pengguna melalui penggunaan sertifikat digital atau metode enkripsi lainnya, menyimpan dan mengirim uang, mengamankan proses pembayaran (Laudon dan Traver, 2013).

\subsection{Partial Least Square (PLS)}

PLS adalah structural equation modeling (SEM) yang berbasis varian, dimana SEM yaitu salah satu kajian bidang statistika yang dapat digunakan untuk mengatasi masalah penelitian, dengan variabel bebas meupun variabel respon adalah variabel yang tak terukur. Pengamatan pada variabel laten dilakukan melalui efek dari variabel indikator, sehingga model PLS yang digunakan dalam penelitian adalah model reflektif (arah hubungan kausalitas dari variabel laten ke indikator). PLS merupakan metode alternatif dari SEM yang powerfull atau sering disebut dengan soft modeling karena tidak mensyaratkan harus memenuhi asumsi-asumsi OLS regresi (data harus berdistribusi normal multivariat dan tidak adanya multikolinieritas antar variabel), skala pengukuran dan jumlah sampel. Secara filosofis, perbedaan antara CB-SEM dan PLS menurut Wold 
dalam Ghozali (2008) adalah orientasi model persamaan struktural yang digunakan untuk menguji teori atau untuk mengembangkan teori (tujuan prediksi).

Pada PLS terdiri dari tiga set hubungan (1) outer model; (2) inner model; (3) weight relation.

\section{Inner Model}

Model ini menspesifikasikan hubungan antar variabel laten berdasarkan teori, dimana antar variabel diasumsikan memiliki hubungan yang linier dan memiliki hubungan sebab akibat. Persamaan inner model ditulis di bawah ini :

\section{Outer Model Hubungan Reflektif}

$$
\boldsymbol{\eta}_{j}=\sum_{k=1}^{k_{i}} \gamma_{j k} \xi_{j}+\sum_{i=1}^{i_{i}} \beta_{j i} \boldsymbol{\eta}_{i}+\zeta_{j}
$$

Outer model menspesifikasikan hubungan antar variabel laten dengan indikatornya. Pada hubungan reflektif, indikator adalah cerminan atau manifiestasi dari variabel latennya. Indikator $X_{j k}$ dan $Y_{j k}$ diasumsikan sebagai fungsi linier dari variabel latennya $\xi_{\mathrm{j}}$ dan $\eta_{\mathrm{j}}$ adalah sebagai berikut :

$$
\begin{array}{ll}
\mathbf{X}_{\mathbf{j k}}=\lambda_{\mathbf{j k}} \boldsymbol{\xi}_{\mathbf{j}}+\boldsymbol{\delta}_{\mathbf{j k}} & \text { untuk variabel eksogen } \\
\boldsymbol{Y}_{\boldsymbol{j} \boldsymbol{k}}=\boldsymbol{\lambda}_{\boldsymbol{j} \boldsymbol{k}} \boldsymbol{\eta}_{\mathbf{j}}+\boldsymbol{\varepsilon}_{\boldsymbol{j} \boldsymbol{k}} & \text { untuk variabel endogen }
\end{array}
$$

dengan $\boldsymbol{\lambda}_{\mathbf{j k}}$ adalah koefisien loading, $\boldsymbol{\delta}_{\mathbf{j k}}$ dan $\boldsymbol{\varepsilon}_{\boldsymbol{j} \boldsymbol{k}}$ adalah residual.

\section{Weight Relation}

Weight relation digunakan untuk mengestimasi nilai dari variabel laten denga rumus sebagai berikut :

$$
\begin{aligned}
& \xi_{\mathrm{j}}=\sum_{\mathrm{k}=1}^{\mathrm{k}_{\mathrm{i}}} \mathrm{W}_{\mathrm{jk}} \mathrm{X}_{\mathrm{jk}}, \mathrm{k}=1,2, \ldots, \mathrm{k}_{\mathrm{i}} \text { untuk variabel eksogen } \\
& \eta_{\mathrm{j}}=\sum_{\mathrm{k}=1}^{\mathrm{k}_{\mathrm{i}}} \mathrm{W}_{\mathrm{jk}} \mathrm{Y}_{\mathrm{jk}}, \mathrm{k}=1,2, \ldots, \mathrm{k}_{\mathrm{i}} \text { untuk variabel endogen }
\end{aligned}
$$

dengan $k_{i}$ adalah banyaknya variabel indikator untuk setiap variabel laten dan $W_{j k}$ adalah $\mathrm{k}$ weight relation yang digunakan untuk membentuk variabel laten $\xi_{\mathrm{j}}$ dan $\eta_{\mathrm{j}}$.

Ketika suatu model telah ditetapkan, langkah selanjutnya adalah melakukan estimasi dengan menggunakan algoritme PLS untuk mengestimasi variabel laten (skor faktor) dengan teknik iterasi. Tahapan-tahapan algoritme disajikan pada gambar 1.

Pada PLS terdiri dari dua model yaitu model struktural dan model pengukuran, oleh karena itu evaluasi model terdiri dari dua tahap yaitu validasi model pengukuran (outer model) dan evaluasi model struktural (inner model). Validasi model pengukuran dilakukan dengan menggunakan reliabiltas dan vailiditas dari indikator-indikator yang membentuk variabel laten. Pada penelitian ini hubungan yang dibangun antara indikator dengan variabel latenya adalah hubungan reflektif. Ada 4 hal yang perlu diperhatikan dengan model reflektif yaitu :

1) Reliabilitas Indikator

Reliabilitas indikator diukur dengan melihat nilai koefisien hubungan setiap indikator terhadap variabel laten harus lebih besar dari 0,6 sehingga dapat dikatakan reliabel.

2) Composite Reliability $\left(\rho_{\mathrm{c}}\right)$

Nilai composite reliability $\left(\rho_{\mathrm{c}}\right)$ digunakan untuk mengukur konsistensi dari blok indikator. Direkomendasikan nilai composite reliability $\left(\rho_{\mathrm{c}}\right)$ lebih besar dari 0,6 (Hair et al. , 2014). Composite reliability $\left(\rho_{\mathrm{c}}\right)$ dapat dihitung dengan rumus sebagai berikut :

$$
\rho_{c}=\frac{\left(\sum_{k} \lambda_{j k}\right)^{2}}{\left(\sum_{k} \lambda_{j k}\right)^{2}+\sum_{k} \operatorname{var}\left(\varepsilon_{j k}\right)}
$$

\section{Convergent Validity}


Cara untuk menguji kevalidan dari konvergensi outer weight adalah dengan melihat nilai Average Variance Extracted (AVE) yang harus lebih besar dari 0,5 (Hair et al. , 2014). Nilai AVE didapatkan dengan rumus sebagai berikut :

$$
A V E=\frac{\sum_{k} \lambda^{2}{ }_{j k}}{\sum_{k} \lambda^{2}{ }_{j k}+\sum_{k} \operatorname{var}\left(\varepsilon_{j k}\right)}
$$

\section{Discriminant Validity}

Validitas diskriminan indikator dapat dilihat pada cross-loading antara indikator dengan variabel latennya. Jika korelasi variabel laten dengan indikator lebih besar daripada ukuran variabel laten lainnya, maka hal itu menunjukkan bahwa variabel laten memprediksi ukuran pada blok mereka lebih baik daripada ukuran blok lainnya (Ghozali, 2008).

Pada evaluasi model struktural ada beberapa cara untuk menilainya, salah satunya kualitas model struktural dievaluasi melalui pengujian $R^{2}$ (Ghozali dan Latan, 2014). Setelah evaluasi model pengukuran dan struktural terpenuhi maka dilanjutkan dengan tahap pengujian hipotesis. PLS tidak mengasumsikan data berdistribusi normal, sebagai gantinya PLS bergantung pada prosedur bootstrap non parametrik untuk menguji signifikansi koefisiennya (Hair, et al. , 2014).

Hipotesis statistik untuk outer model:

$H_{0}: \lambda_{j k}=0$

$H_{1}: \lambda_{j k} \neq 0$

Hipotesis statistik untuk inner model:

$H_{0}: \beta_{i}=0 \quad$ atau $\quad H_{1}: \gamma_{i}=0$

$H_{0}: \beta_{i} \neq 0 \quad$ atau $\quad H_{1}: \gamma_{i} \neq 0$

Statistik uji yang digunakan adalah uji t, dengan rumus sebagai berikut :

$t_{\text {hitung }}=\frac{\widehat{\lambda}_{j k}}{S E^{*}\left(\widehat{\lambda}_{j k}\right)}$, untuk uji terhadap outer model

$t_{\text {hitung }}=\frac{\widehat{\beta}_{j k}}{S E^{*}\left(\widehat{\beta}_{j k}\right)}$, untuk uji terhadap inner model endogen - endogen

$t_{\text {hitung }}=\frac{\widehat{\gamma}_{j k}}{S E^{*}\left(\widehat{\gamma}_{j k}\right)}$, untuk uji terhadap inner model eksogen - endogen

$\mathrm{SE}^{*}$ (dugaan parameter) adalah standar error yang diperoleh dari bootstrapping. Kriteria uji adalah $H_{0}$ ditolak jika nilai $\left|t_{\text {hitung }}\right|>Z_{\frac{\alpha}{2}}=1,96$ (Hair et al. , 2014).

Dalam praktiknya pada tahap evaluasi model dan pengujian hipotesis selalu terpenuhi, sehingga dilakukan teori trimming. Teori trimming merupakan metode yang digunakan guna memperbaiki model analisis jalur dengan cara menghilangkan atau menghapus koefisien yang tidak signifikan dan tidak memenuhi kriteria pada evaluasi model. Setelah trimming dilakukan selanjutnya dilakukan pemodelan PLS kembali. Pemodelan baru yang telah memenuhi evaluasi model dan uji hipotesis akan dilakukan analisis Moderating Structural Equation Modeling (MSEM) dengan metode ping.

Salah satu metode yang dapat digunakan untuk menilai pengaruh moderasi adalah dengan metode Ping. Metode ini menggunakan indikator tunggal dengan cara mengalikan indikator dari variabel laten eksogen dengan indikator dari variabel moderatornya. Suatu variabel dikatakan memoderasi pengaruh antara variabel bebas terhadap variabel terikat jika koefisien jalur antara variabel interaksi signifikan. Hair et. al, (2014) mengasumsikan bahwa koefisien jalur berbeda secara signifikan pada taraf signifikansi $5 \%$ jika nilai $\left|t_{\text {hitung }}\right|>Z_{\frac{\alpha}{2}}=1,96$. 

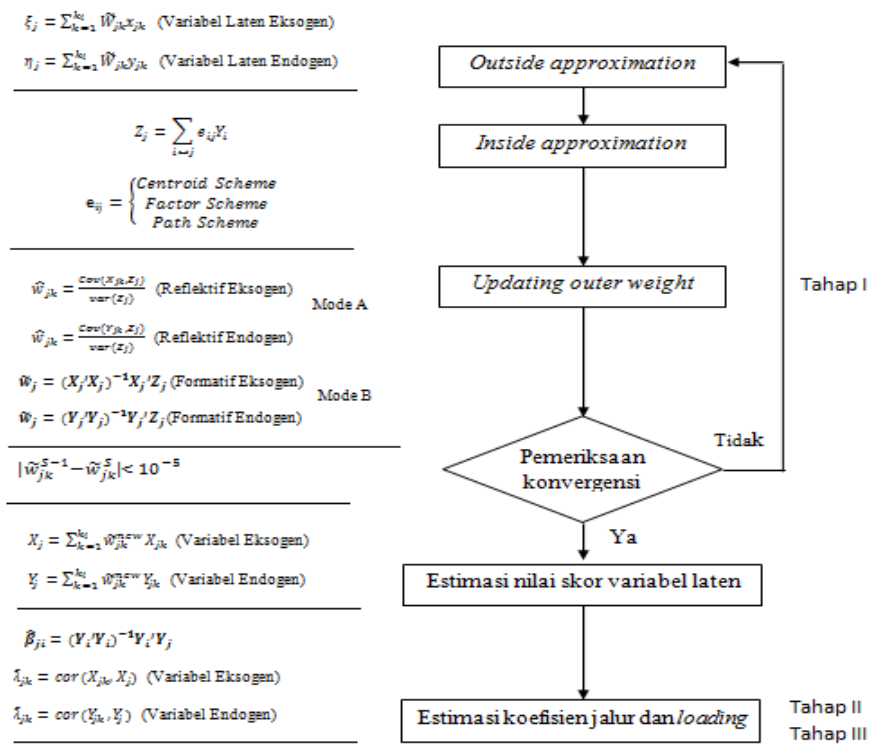

\section{METODE PENELITIAN}

Gambar 1. Algoritma PLS

\subsection{Data Penelitian}

Pengambilan lokasi penelitian ini adalah di Kota Semarang. Teknik pengambilan sampel menggunakan purposive sampling dengan kriteria mempunyai produk dompet digital ( $e$-wallet) dan sudah pernah menggunakannya. Ukuran sampel yang digunakan sebesar 147. Jenis data yang digunakan adalah data primer dengan skala interval 1-10. Pada penelitian ini terdapat 32 indikator, 7 variabel laten dan 1 variabel moderator. Variabel laten eksogen terdiri dari social influence, hedonic motivation, price and value, faciliating conditions dan habit. Variabel endogen terdiri dari behavioral intentions dan use behavior, untuk variabel moderator adalah experience.

\subsection{Metode Analisis Data}

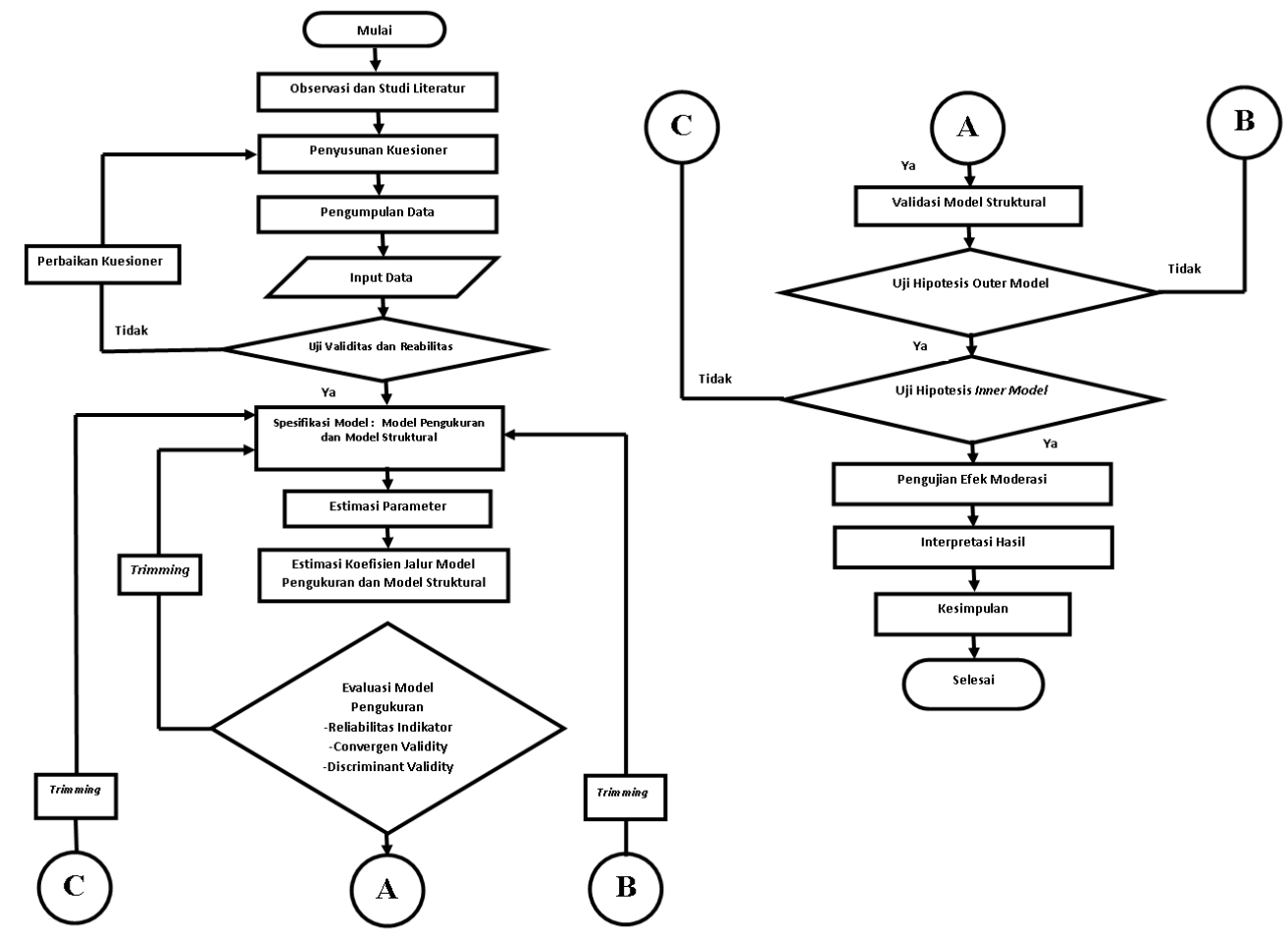

Gambar 2. Diagram Alur (Flow Chart) Penelitian 


\section{HASIL DAN PEMBAHASAN}

\subsection{Pemodelan Penerimaan dan Penggunaan Dompet Digital (E-wallet)}

Pada model I pada tahap evaluasi model pengukuran didapatkan hasil bahwa indikator $X_{13}, X_{24}, X_{46}$ dan $Y_{24}$ tidak memenuhi uji reliabilitas indikator karena memiliki nilai outer loading yang kurang dari 0,6, uji composite reiability terpenuhi karena semua variabel penelitian memiliki composite reliability >0,6, uji convergent validity tidak terpenuhi karena social influence, faciliating conditions dan use behavior memiliki nilai AVE yang kurang dari 0,5 dan uji discriminant validity tidak terpenuhi karena pada cross loading ada beberapa nilai korelasi antar indikator dengan variabel laten lainnya tidak paling tinggi dibandingkan pada variabel lain. Berdasarkan validasi model pengukuran tersebut yang belum sepenuhnya terpenuhi maka model dikonstruksi ulang dengan melakukan trimming. Indikator yang akan dihapus untuk membentuk model baru adalah $X_{13}, X_{24}, X_{46}$ dan $Y_{24}$.

Setelah trimming dilakukan dilanjutkan dengan pemodelan baru (model II), hasil evaluasi outer model adalah sebagai berikut :

a. Reliabilitas Indikator

Pada model II ini semua indikator mempunyai nilai outer loading yang lebih dari 0,6. Sehingga dapat disimpulkan bahwa semua koefisien hubungan indikator memenuhi uji reliabilitas indikator.

b. Composite Realiability

Tabel 1. Nilai Composite Realiability

\begin{tabular}{|l|c|l|c|}
\hline \multicolumn{1}{|c|}{ Variabel } & Composite Reliability & \multicolumn{1}{c|}{ Variabel } & Composite Reliability \\
\hline Behavioral Intentions & 0,841 & Price and Value & 0,862 \\
\hline Faciliating Conditions & 0,838 & Social Influence & 0,860 \\
\hline Habit & 0,821 & Use Behavior & 0,808 \\
\hline HedonicMotivation & 0,860 & \multicolumn{3}{|c}{} \\
\cline { 1 - 3 } & &
\end{tabular}

Nilai composite reliability pada semua blok indikator > 0,6 maka telah memenuhi uji composite reliability. Hal ini menunjukkan bahwa blok indikator pada masingmasing variabel laten memiliki konsistensi yang tinggi.

c. Convergent Validity

Uji convergent validity terpenuhi karena nilai AVE masing-masing variabel laten lebih besar dari 0,5. Hal ini menunjukkan bahwa outer weight setiap indikator variabel laten yang sudah konvergen adalah valid.

Tabel 2. Nilai AVE

\begin{tabular}{|l|c|l|c|}
\hline \multicolumn{1}{|c|}{ Variabel } & $\mathrm{AVE}$ & \multicolumn{1}{|c|}{ Variabel } & $\mathrm{AVE}$ \\
\hline Behavioral Intentions & 0,516 & Price and Value & 0,611 \\
\hline Faciliating Conditions & 0,510 & Social Influence & 0,551 \\
\hline Habit & 0,607 & Use Behavior & 0,584 \\
\hline HedonicMotivation & 0,671 & \multicolumn{3}{|l}{} \\
\cline { 1 - 2 } & &
\end{tabular}

\section{d. Discriminant Validity}

Output cross loading model II menunjukkan bahwa semua nilai korelasi antar indikator dengan variabel latennya paling tinggi dibandingkan pada variabel lain, artinya variabel laten mampu memprediksi indiktornya lebih baik dibandingkan variabel laten lainnya. Sehingga dapat disimpulkan bahwa semua indikator memenuhi uji ini.

Tahapan selanjutnya setelah evaluasi outer model terpenuhi adalah evaluasi inner model menggunakan nilai $R^{2}$. Berdasarkan hasil analisis dengan menggunakan software SmartPLS diperoleh $R_{1}^{2}=0,846$ dan $R_{2}^{2}=0,661$. Hal ini menunjukkan bahwa variabel 
behavioral intentions dapat dijelaskan dengan baik oleh variabel social influence, hedonic motivation, price and value, faciliating conditions dan habit sebesar 84,6\% dan sisanya $15,4 \%$ dijelaskan oleh variabel lain diluar penelitian. Variabel use behavior dapat dijelaskan dengan baik oleh variabel behavioral intentions, faciliating conditions dan habit sebesar $66,1 \%$ dan sisanya 33,9\% dijelaskan oleh variabel lain di luar penelitian. Evaluasi model struktural sudah terpenuhi selanjutnya dilakukan pengujian hipotesis.

PLS tidak mengasumsikan bahwa data berdistribusi normal maka digunakan teknik resampling dengan metode bootstrapping. Hasil dari bootstrapping dengan sampel bootstrap sebanyak 5000 kali diasumsikan data telah berdistribusi normal sehingga pengujian parameter dalam model dapat dilakukan dengan uji t. Nilai koefisien dari model struktural dikatakan signifikan jika nilai $t_{\text {hitung }}>Z_{(0,025)}=1,96$.

Berikut hasil uji hipotesis :

Tabel 3. Uji Outer Model

\begin{tabular}{|l|c|c|c|c|c|c|c|c|c|}
\hline Loading & $\begin{array}{c}\text { Nilai } \\
\text { Outer } \\
\text { Loading }\end{array}$ & $\begin{array}{c}\text { Standar } \\
\mathrm{d} \text { Error }\end{array}$ & $t_{\text {hitung }}$ & Keputusan & Loading & $\begin{array}{c}\text { Nilai } \\
\text { Outer } \\
\text { Loading }\end{array}$ & $\begin{array}{c}\text { Standar } \\
\mathrm{d} \text { Error }\end{array}$ & $t_{\text {hitung }}$ & Keputusan \\
\hline$\xi_{1} \rightarrow X_{11}$ & 0,682 & 0.103 & 6.653 & $H_{0}$ ditolak & $\xi_{4} \rightarrow X_{43}$ & 0,685 & 0.113 & 6.080 & $H_{0}$ ditolak \\
\hline$\xi_{1} \rightarrow X_{12}$ & 0,714 & 0.111 & 6.427 & $H_{0}$ ditolak & $\xi_{4} \rightarrow X_{44}$ & 0,674 & 0.131 & 5.140 & $H_{0}$ ditolak \\
\hline$\xi_{1} \rightarrow X_{14}$ & 0,800 & 0.082 & 9.795 & $H_{0}$ ditolak & $\xi_{4} \rightarrow X_{45}$ & 0,675 & 0.111 & 6.057 & $H_{0}$ ditolak \\
\hline$\xi_{1} \rightarrow X_{15}$ & 0,790 & 0.092 & 8.548 & $H_{0}$ ditolak & $\xi_{5} \rightarrow X_{51}$ & 0,672 & 0.156 & 4.316 & $H_{0}$ ditolak \\
\hline$\xi_{1} \rightarrow X_{16}$ & 0,719 & 0.094 & 7.687 & $H_{0}$ ditolak & $\xi_{5} \rightarrow X_{52}$ & 0,788 & 0.110 & 7.135 & $H_{0}$ ditolak \\
\hline$\xi_{2} \rightarrow X_{21}$ & 0,820 & 0.074 & 11.117 & $H_{0}$ ditolak & $\xi_{5} \rightarrow X_{53}$ & 0,866 & 0.034 & 25.779 & $H_{0}$ ditolak \\
\hline$\xi_{2} \rightarrow X_{22}$ & 0,818 & 0.051 & 15.911 & $H_{0}$ ditolak & $\eta_{1} \rightarrow Y_{11}$ & 0,780 & 0.076 & 10.234 & $H_{0}$ ditolak \\
\hline$\xi_{2} \rightarrow X_{23}$ & 0,821 & 0.059 & 14.003 & $H_{0}$ ditolak & $\eta_{1} \rightarrow Y_{12}$ & 0,707 & 0.118 & 5.983 & $H_{0}$ ditolak \\
\hline$\xi_{3} \rightarrow X_{31}$ & 0,831 & 0.063 & 13.178 & $H_{0}$ ditolak & $\eta_{1} \rightarrow Y_{13}$ & 0,712 & 0.101 & 7.035 & $H_{0}$ ditolak \\
\hline$\xi_{3} \rightarrow X_{32}$ & 0,840 & 0.045 & 18.468 & $H_{0}$ ditolak & $\eta_{1} \rightarrow Y_{14}$ & 0,770 & 0.106 & 7.279 & $H_{0}$ ditolak \\
\hline$\xi_{3} \rightarrow X_{33}$ & 0,748 & 0.098 & 7.649 & $H_{0}$ ditolak & $\eta_{1} \rightarrow Y_{15}$ & 0,610 & 0.136 & 4.491 & $H_{0}$ ditolak \\
\hline$\xi_{3} \rightarrow X_{34}$ & 0,699 & 0.097 & 7.185 & $H_{0}$ ditolak & $\eta_{2} \rightarrow Y_{21}$ & 0,719 & 0.128 & 5.607 & $H_{0}$ ditolak \\
\hline$\xi_{4} \rightarrow X_{41}$ & 0,780 & 0.085 & 9.150 & $H_{0}$ ditolak & $\eta_{2} \rightarrow Y_{22}$ & 0,752 & 0.100 & 7.513 & $H_{0}$ ditolak \\
\hline$\xi_{4} \rightarrow X_{42}$ & 0,750 & 0.141 & 5.324 & $H_{0}$ ditolak & $\eta_{2} \rightarrow Y_{23}$ & 0,819 & 0.127 & 6.424 & $H_{0}$ ditolak \\
\hline
\end{tabular}

Tabel 4. Uji Hipotesis Hubungan antar Variabel

\begin{tabular}{|l|c|c|c|c|c|c|c|c|c|}
\hline $\begin{array}{l}\text { Pengaruh } \\
\text { Variabel }\end{array}$ & $\begin{array}{c}\text { Estimasi } \\
\text { Koefisie } \\
\text { n Jalur }\end{array}$ & $\begin{array}{c}\text { Nilai } \\
\text { Error }\end{array}$ & $t_{\text {hitung }}$ & Keterangan & $\begin{array}{l}\text { Pengaruh } \\
\text { Variabel }\end{array}$ & $\begin{array}{c}\text { Estimasi } \\
\text { Koefisie } \\
\text { n Jalur }\end{array}$ & $\begin{array}{c}\text { Nilai } \\
\text { Error }\end{array}$ & $t_{\text {hitung }}$ & Keterangan \\
\hline $\begin{array}{l}\text { Social } \\
\text { Influence-> } \\
\text { Behavioral } \\
\text { Intentions }\end{array}$ & 0,150 & 0,074 & 2,038 & $H_{0}$ ditolak & $\begin{array}{l}\text { Faciliating } \\
\text { Conditions } \\
->\text { Use } \\
\text { Behavior }\end{array}$ & 0,487 & 0,168 & 2,904 & $H_{0}$ ditolak \\
\hline $\begin{array}{l}\text { Hedonic } \\
\text { Motivation- } \\
> \\
\text { Behavioral } \\
\text { Intentions }\end{array}$ & 0,210 & 0,121 & 1,740 & $H_{0}$ diterima & $\begin{array}{l}\text { Habit -> } \\
\text { Behavioral } \\
\text { Intentions }\end{array}$ & 0,427 & 0,119 & 3,598 & $H_{0}$ ditolak \\
\hline $\begin{array}{l}\text { Priceand } \\
\text { Value -> } \\
\text { Behavioral } \\
\text { Intentions }\end{array}$ & 0,002 & 0,118 & 0,013 & $H_{0}$ diterima & $\begin{array}{l}\text { Habit -> } \\
\text { Use } \\
\text { Behavior }\end{array}$ & $-0,187$ & 0,164 & 1,136 & $H_{0}$ diterima \\
\hline $\begin{array}{l}\text { Faciliating } \\
\text { Conditions - } \\
> \\
\text { Behavioral } \\
\text { Intentions }\end{array}$ & 0,290 & 0,138 & 2,093 & $H_{0}$ ditolak & $\begin{array}{l}\text { Behavioral } \\
\text { Intentions - } \\
\text { Use } \\
\text { Behavior }\end{array}$ & 0,513 & 0,209 & 2,451 & $H_{0}$ ditolak \\
\hline
\end{tabular}

Berdasarkan Tabel koefisien loading untuk setiap indikator dalam masing-masing variabel laten signifikan. Berdasarkan hasil uji hipotesis Tabel 14 social influence, 
faciliating conditions dan habit berpengaruh terhadap behavioral intentions. Behavioral intentions dan faciliating conditions berpengaruh terhadap use behavior. Uji hipotesis inner model belum sepenuhnya terpenuhi karena adanya variabel yang tidak berpengaruh, sehingga model harus dikonstruksi ulang dengan melakukan trimming yaitu menghilangkan koefisien jalur yang tidak berpengaruh yaitu koefisien jalur antara hedonic motivation dengan behavioral intentions, koefisien jalur antara price and value dengan behavioral intentions dan koefisien jalur antara habit dengan use behavior.

Adanya trimming menghasilkan model akhir dengan 21 model pengukuran (outer model) untuk 21 indikator yaitu $X_{11}, X_{12}, X_{14}, X_{15}, X_{16}, X_{41}, X_{42}, X_{43}, X_{44}, X_{45}, X_{51}, X_{52}$, $X_{53}, Y_{11}, Y_{12}, Y_{13}, Y_{14}, Y_{15}, Y_{21}, Y_{22}$, dan $Y_{23}$. Selain itu, ada dua model struktural (inner model) yaitu model struktural behavioral intentions yang dijelaskan oleh variabel social influence, faciliating conditions dan habit, serta model struktural use behavior yang dijelaskan oleh variabel behavioral intentions dan faciliating conditions. Berdasarkan hasil analisis Smart-PLS diperoleh nilai $R_{1}^{2}=0,818$ dan $R_{2}^{2}=0,651$. Hal ini menunjukkan bahwa variabel behavioral intentions dapat dijelaskan dengan baik oleh variabel social influence, faciliating conditions dan habit sebesar 81,8\% dan sisanya 18,2\% dijelaskan oleh variabel lain diluar penelitian. Variabel use behavior dapat dijelaskan dengan baik oleh variabel behavioral intentions dan faciliating conditions sebesar $65,1 \%$ dan sisanya $34,9 \%$ dijelaskan oleh variabel lain di luar penelitian. Pada penelitian ini terdapat pengaruh langsung, pengaruh tidak langsung dan pengaruh total dari variabel eksogen ke variabel endogen, adapun hasil analisis pengaruh tersebut disajikan pada tabel 5.

Tabel 5. Pengaruh antar Variabel Laten

\begin{tabular}{|c|c|c|c|c|c|}
\hline \multicolumn{3}{|c|}{ Variabel } & \multicolumn{3}{|c|}{ Pengaruh } \\
\hline Endogen & Eksogen & Intervening & Langsung & $\begin{array}{c}\text { Tak } \\
\text { Langsung }\end{array}$ & Total \\
\hline \multirow{3}{*}{$\eta_{1}$} & $\xi_{1}$ & & 0,183 & & 0,183 \\
\cline { 2 - 4 } & $\xi_{4}$ & & 0,366 & & 0,366 \\
\cline { 2 - 4 } & $\xi_{5}$ & & 0,467 & & 0,467 \\
\hline \multirow{3}{*}{$\eta_{2}$} & $\xi_{1}$ & \multirow{2}{*}{$\eta_{1}$} & & 0,068 & 0,068 \\
\cline { 2 - 4 } & $\xi_{4}$ & & 0,469 & 0,137 & 0,605 \\
\cline { 2 - 4 } & $\xi_{5}$ & & 0,175 & 0,175 \\
\cline { 2 - 5 } & $\eta_{1}$ & & 0,374 & & 0,374 \\
\hline
\end{tabular}

Berdasarkan analisis-analis sebelumnya yang telah dilakukan dengan menggunakan Smart-PLS diperoleh outer model terbaik dan inner model untuk penelitian ini yaitu

$>$ Outer model untuk variabel social influence
$X_{11}=0,682 \xi_{1}+\delta_{11}$
$X_{15}=0,790 \xi_{1}+\delta_{15}$
$X_{12}=0,713 \xi_{1}+\delta_{12}$
$X_{16}=0,719 \xi_{1}+\delta_{16}$
$X_{14}=0,800 \xi_{1}+\delta_{14}$

$>$ Outer model untuk variabel faciliating conditions

$\begin{array}{ll}X_{41}=0,779 \xi_{4}+\delta_{41} & X_{45}=0,674 \xi_{4}+\delta_{45} \\ X_{42}=0,750 \xi_{4}+\delta_{42} & X_{46}=0,674 \xi_{1}+\delta_{46}\end{array}$

$X_{43}=0,686 \xi_{4}+\delta_{43}$

$>$ Outer model untuk variabel habit

$X_{51}=0,686 \xi_{5}+\delta_{51}$

$X_{52}=0,785 \xi_{5}+\delta_{52}$

$X_{53}=0,860 \xi_{5}+\delta_{53}$

$>$ Outer model untuk variabel behavioral intentions
$Y_{11}=0,781 \eta_{1}+\varepsilon_{11}$
$Y_{12}=0,709 \eta_{1}+\varepsilon_{12}$
$Y_{14}=0,769 \eta_{1}+\varepsilon_{14}$
$Y_{15}=0,611 \eta_{1}+\varepsilon_{15}$

$Y_{13}=0,708 \eta_{1}+\varepsilon_{13}$

Outer model untuk variabel use behavior 


$$
\begin{aligned}
& Y_{21}=0,722 \eta_{2}+\varepsilon_{21} \\
& Y_{22}=0,754 \eta_{2}+\varepsilon_{22} \\
& \text { Inner model untuk behavioral intentions }
\end{aligned} \quad Y_{23}=0,814 \eta_{2}+\varepsilon_{23}
$$

$$
\eta_{1}=0,183 \xi_{1}+0,366 \xi_{4}+0,467 \xi_{5}
$$

Berdasarkan model tersebut diketahui bahwa behavioral intentions $\left(\eta_{1}\right)$ dijelaskan dengan baik oleh variabel social influence $\left(\xi_{1}\right)$, faciliating conditions $\left(\xi_{4}\right)$ dan habit $\left(\xi_{5}\right)$.

Inner model untuk use behavior

$$
\eta_{2}=0,469 \xi_{4}+0,374 \eta_{1}
$$

Berdasarkan model tersebut diketahui bahwa use behavior dijelaskan dengan baik oleh variabel behavioral intentions $\left(\eta_{1}\right)$ dan faciliating conditions $\left(\xi_{4}\right)$.

Setelah didapatkan model penerimaan dan penggunaan dompet digital ( $e$-wallet), maka dilakukan analisis MSEM dengan metode ping. Pengalaman menjadi variabel moderasi dalam penelitian ini. Diagram jalur model MSEM disajikan pada gambar 3 dan hasilnya disajikan pada tabel 6. Pengujian hipotesis dilakukan dengan cara membandingkan $t_{\text {hitung }}$ dengan $Z_{\text {tabel } \frac{\alpha}{2}}$ serta melihat koefisien jalurnya, dimana nilai $t_{\text {hitung }}$ diperoleh dengan menggunakan metode bootstrapping.

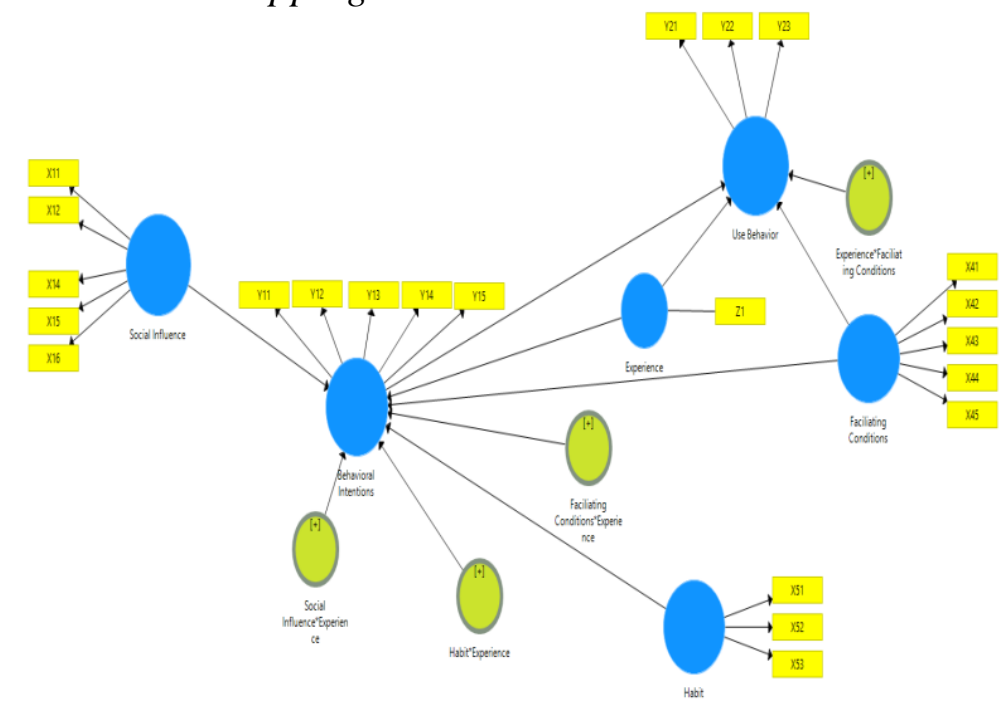

Gambar 3. Diagram Jalur Model MSEM

Tabel 6. Hasil Pengujian Koefisien Jalur Variabel Moderasi

\begin{tabular}{|l|c|c|c|c|}
\hline \multicolumn{1}{|c|}{ Pengaruh Variabel } & $\begin{array}{c}\text { Estimasi } \\
\text { Koefisien } \\
\text { Jalur }\end{array}$ & $\begin{array}{c}\text { Nilai } \\
\text { Error }\end{array}$ & $t_{\text {hitung }}$ & Keterangan \\
\hline $\begin{array}{l}\text { Social Influence*Experience-> } \\
\text { Behavioral Intentions }\end{array}$ & $-0,173$ & 0,161 & 1,080 & $H_{0}$ diterima \\
\hline $\begin{array}{l}\text { Faciliating } \\
\begin{array}{l}\text { Conditions *xperience-> } \\
\text { Behavioral Intentions }\end{array}\end{array}$ & 0,463 & 0,375 & 1,235 & $H_{0}$ diterima \\
\hline $\begin{array}{l}\text { Faciliating } \\
\text { Conditions } * \text { Experience-> Use } \\
\text { Behavior }\end{array}$ & $-0,532$ & 0,274 & 1,942 & $H_{0}$ diterima \\
\hline $\begin{array}{l}\text { Habit*Experience -> } \\
\text { Behavioral Intentions }\end{array}$ & $-0,274$ & 0,336 & 0,815 & $H_{0}$ diterima \\
\hline
\end{tabular}

Berdasarkan tabel di atas diperoleh hasil bahwa semua $H_{0}$ diterima variabel moderasi pengalaman tidak memiliki hubungan dengan social influence, faciliating conditions dan habit yang signifikan dalam mempengaruhi behavioral intentions dan use 
behavior, sehingga dapat disimpulkan pengalaman tidak bersifat memperkuat atau memperlemah (memoderasi) model penerimaan dan penggunaan dompet digital ( $e$-wallet).

\section{KESIMPULAN}

Berdasarkan hasil analisa data dan pembahasan dengan metode Partial Least Square (PLS) secara keseluruhan dapat disimpulkan sebagai berikut :

1. Berdasarkan hasil penelitian diperoleh 21 model pengukuran (outer model) dan 2 model struktural (inner model).

2. Berdasarkan hasil pengujian hipotesis variabel social influence, faciliating condiions dan habit memberikan pengaruh yang positif dan signifikan, sedangkan variabel hedonic motivation dan price and value tidak signifikan terhadap behavioral intentions. Variabel behavioral intentions dan faciliating conditions memilki pengaruh postif dan signifikan terhadap use behavior.

3. Berdasarkan analisis MSEM dengan metode ping diproleh hasil bahwa variabel experience tidak memoderasi hubungan antar variabel dalam model penerimaan dan penggunaan dompet digital ( $e$-wallet), artinya pengalaman tidak bersifat memperkuat atau memperlemah hubungan antar variabel dalam model tersebut.

\section{DAFTAR PUSTAKA}

Brown, S. A., \& Vankatesh, V. (2005). Model of Adoption of Technology in the Household: A Baseline Model Test and Extension Incorporating Household Life Cycle. MIS Quarterly, Vol. 29, no.4, Hal. 399-426.

Ghozali, I. (2008). Structural Equation Modelling Metode Alternatif dengan Partial Least Square (PLS) Edisi 3. Semarang: Badan Penerbit Universitas Diponegoro.

Hair, J. F., Hult, G. T., Ringle, C. M., \& Sartest, M. G. (2014). A Primer On Partial Least Squares Structural Equation Modeling (PLS-SEM). United States of America: SAGE.

Harsono, L. D., \& Suryana, L. A. (2014). Factors Affecting the Use Behavior of Social Media Using UTAUT 2 Model. Procedings of The First Asia-PacififConference on Global Business, Economics, Finance and Social Sciences(AP14Singapore Conference) , Hal. 1-14.

Jusuf, H., Ningsih, S., Widjanarko, B., \& Suharsono, A. (2016). Pemodelan Infeksi Opurtunistik Pada Kasus HIV/AIDS dengan Moderating Kepatuhan Terapi ARV Menggunakan Pendekatan Partial Least Square. Jurnal Statistika Universitas Muhamidayah Semarang, Vol. 4, No. 2.

Laudon, K. C., \& Traver, C. G. (2013). E-Commerce 2013 : business, technology, society. Edinburgh Gate : Pearson.

Ningsi, B. A. (2012). Pemodelan Ketahanan Pangan Indonesia dengan Menggunakan Partial Least Square Path Modelling (PLS-PM). Tesis: Institut Pertanian Bogor.

Pikkarainen, T., Pikkarainen, K., Karjalouto, H., \& Pahnila, S. (2004). Consumer Acceptance of Online Banking: An Extension of The Technology Acceptance Model. Internet Research, Vol. 14 No. 3 Hal. 224-235.

Venkatesh, V., Morris, M. G., Davis, G. B., \& Davis, F. D. (2003). User Acceptance and Use of Information Technology: Toward a Unified View. MIS Quarterly , 425-478. 